\title{
Ecological Setting of the Wind River Old-growth Forest
}

\author{
David C. Shaw, ${ }^{1,2 *}$ Jerry F. Franklin, ${ }^{1,2}$ Ken Bible, ${ }^{1,2}$ Jeffrey Klopatek, ${ }^{3}$ \\ Elizabeth Freeman, Sarah Greene, ${ }^{4}$ and Geoffrey G. Parker ${ }^{5}$
}

\begin{abstract}
${ }^{1}$ Wind River Canopy Crane Research Facility, University of Washington, Carson, Washington 98610, USA; ${ }^{2}$ College of Forest Resources, University of Washington, Seattle, Washington 98195-2100, USA; ${ }^{3}$ Department of Plant Biology, Arizona State University, Tempe, Arizona 85287-1601, USA; ${ }^{4}$ Pacific Northwest Research Station, Forestry Sciences Laboratory, US Forest Service, Corvallis, Oregon 97331, USA; ${ }^{5}$ Smithsonian Environmental Research Center, Edgewater, Maryland 21037-0028, USA
\end{abstract}

\begin{abstract}
The Wind River old-growth forest, in the southern Cascade Range of Washington State, is a cool (average annual temperature, $8.7^{\circ} \mathrm{C}$ ), moist (average annual precipitation, $2223 \mathrm{~mm}$ ), 500-year-old Douglas-fir-western hemlock forest of moderate to low productivity at 371-m elevation on a less than $10 \%$ slope. There is a seasonal snowpack (November-March), and rain-on-snow and freezing-rain events are common in winter. Local geology is characterized by volcanic rocks and deposits of Micocene/Oligocene Micocene-Oligocene (mixed) Micocene and Quaternary age, as well as intrusive rocks of Miocene age. Soils are medial, mesic, Entic Vitrands that are deep (2-3 m), well drained, loams and silt loams, generally stone free, and derived from volcanic tephra. The vegetation is transitional, between the Western Hemlock Zone and the Pacific Silver Fir Zone, and the understory is dominated by vine maple, salal, and Oregon grape. Stand structural parameters have been measured on a 4-ha plot. There are eight species of conifers, with a stand density of 427 trees ha ${ }^{-1}$ and basal area of $82.9 \mathrm{~m}^{2}$ $\mathrm{ha}^{-1}$. Dominant conifers include Douglas-fir (35 trees ha-1), western hemlock (224 trees ha-1), Pa-
\end{abstract}

\section{INTRODUCTION}

The Wind River old-growth forest is an approximately 500-year-old Douglas-fir (Pseudotsuga menziesii)-western hemlock (Tsuga heterophylla) forest

Received 15 February 2002; accepted 31 October 2002; published online 12 May 2004.

*Corresponding author; e-mail: dshaw@u.washington.edu cific yew ( 86 trees $\mathrm{ha}^{-1}$ ), western red cedar (30 trees $\left.\mathrm{ha}^{-1}\right)$, and Pacific silver fir (47 trees ha $\left.{ }^{-1}\right)$. The average height of Douglas-fir is $52.0 \mathrm{~m}$ (tallest tree, $64.6 \mathrm{~m})$, whereas western hemlock averages $19.0 \mathrm{~m}$ (tallest tree, $55.7 \mathrm{~m}$ ). The regional disturbance regime is dominated by high-severity to moderateseverity fire, from which this forest is thought to have originated. There is no evidence that fire has occurred in the forest after establishment. Primary agents of stand disturbance, which act at the individual to small groups of trees scale, are wind, snow loads, and drought, in combination and interacting with root-rot and butt-rot fungi, heart-rot fungi, dwarf mistletoe, and bark beetles. The forest composition is slowly shifting from dominance by Douglas-fir, a shade-intolerant species, to western hemlock, western red cedar, Pacific yew, and Pacific silver fir, all shade-tolerant species. The Wind River old-growth forest fits the regional definition of Douglas-fir "old growth" on western hemlock sites.

Key words: old growth; temperate coniferous forest; ecological characterization; soils; geology; climate; vegetation; disturbance. in the southern Cascade Range of Washington State. The Wind River Canopy Crane Research Facility (WRCCRF) was established in this forest to provide access to the canopy (Figure 1). The crane is a $75-\mathrm{m}$-tall construction tower crane with an 85$\mathrm{m}$ jib that provides three-dimensional access to 1.7 $\times 10^{6} \mathrm{~m}^{3}$ of the canopy over a 2.3-ha "canopy crane circle" via a gondola (personnel basket) 


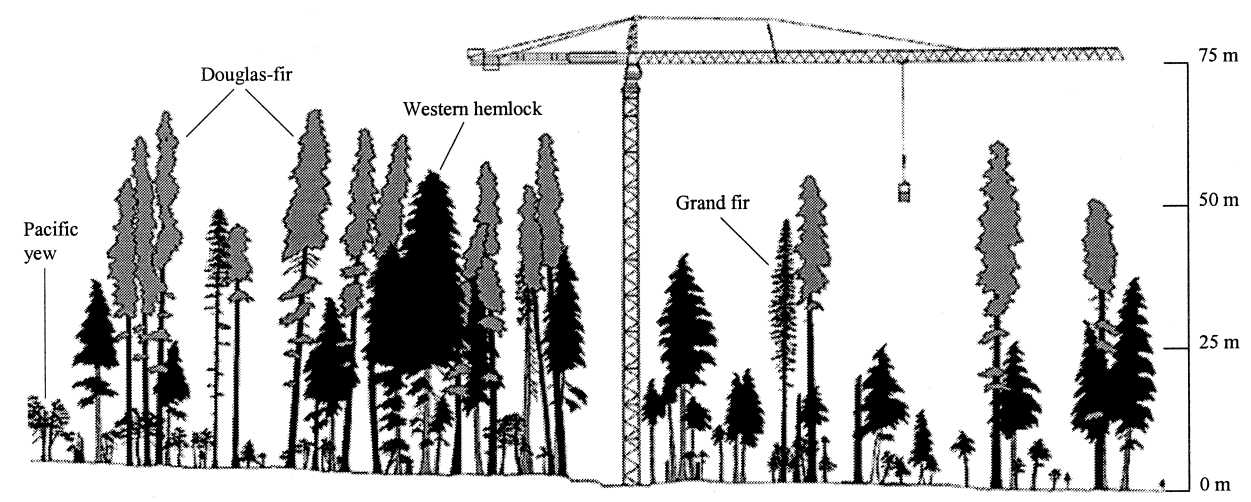

Figure 1. Vertical profile through the old-growth forest at the Wind River Canopy Crane Research Facility (WRCCRF). The drawing includes all trees larger than $5-\mathrm{cm}$ diameter at breast height within a swath $180 \mathrm{~m}$ long and $10 \mathrm{~m}$ wide through the center of the WRCCRF 4-ha plot. The crane is $75 \mathrm{~m}$ tall with an 85 -m-long jib, accessing 2.3 ha of ground area under the swing of the jib. The stand is dominated by Douglas-fir in terms of height, wood volume, and basal area, but western hemlock in terms of number of trees.

suspended from the jib. The College of Forest Resources, University of Washington, USDA Pacific Northwest Research Station (Portland, Oregon, USA) and USDA Gifford Pinchot National Forest (Vancouver, Washington, USA) jointly established the facility in 1995.

In 1997, the Wind River old-growth forest and the WRCCRF were selected as a primary study site for the investigation of forest carbon dynamics by the Western Regional Center (WESTGEC) of the National Institute for Global Environmental Change. Eddy-flux instrumentation was established on the tower of the crane in 1998 at which time the WRCCRF became an Ameriflux site. This report provides an overview of the physical and ecological setting of the Wind River old-growth forest in order to better understand, interpret, and extrapolate the results of the detailed process-based research reported elsewhere in this special feature.

\section{Description OF The Facility}

The quantified forest descriptions provided in this report are based on a 4-ha stem mapped plot that surrounds the canopy crane (WRCCRF 4-ha plot). The site is located in the Wind River valley of the southern Washington Cascade Range, approximately $75 \mathrm{~km}$ east of Portland, Oregon, near Carson, Washington, and located at 371-m elevation, at latitude N 45 $49^{\prime} 13.76^{\prime \prime}$ and longitude W $121^{\circ} 57^{\prime} 06.88^{\prime \prime}$. The valley emerges into a major geographic feature, the Columbia River Gorge, about $15 \mathrm{~km}$ south of the crane site (Figure 2). Administratively, the Wind River old-growth forest and the canopy crane are located within the T. T. Munger Research Natural Area, and the Trout
Creek Division of the Gifford Pinchot National Forest's Wind River Experimental Forest. The Wind River Experimental Forest (WREF) is a 4208-ha area formally dedicated to scientific and educational purposes by the USDA Forest Service in 1932 and has been an active forest research site since 1908. The T. T. Munger Research Natural Area (RNA) is a 478-ha old-growth forest preserve (about 500 years old) within the WREF and is dominated by Douglas-fir and western hemlock. The RNA was selected for protection in 1926 and expanded in size in 1934, as an area representative of the widespread old-growth Douglas-fir forests found west of the crest of the Cascade Range in Washington and Oregon (Franklin 1972). USDA Forest Service Pacific Northwest Research Station and Gifford Pinchot National Forest are jointly responsible for administration of the Experimental Forest and Research Natural Area.

\section{Natural and Human Geography}

The defining geographic feature of the Wind River old-growth forest area is the north-southoriented Cascade Range and the Columbia River Gorge, $15 \mathrm{~km}$ south, which provides a water-grade east-west pathway through the range. The Cascade Range extends from northern California to southern British Columbia, with a width of 75-100 km in the central region. Major divides are typically 1000- to 2000-m elevation, with volcanic cones occasionally reaching 3500-m elevation. The Cascade Range is a major barrier to the primarily easterly flow of marine air masses from the Pacific Ocean. Consequently, clouds are abundant and rainfall increases rapidly on the western slopes of 


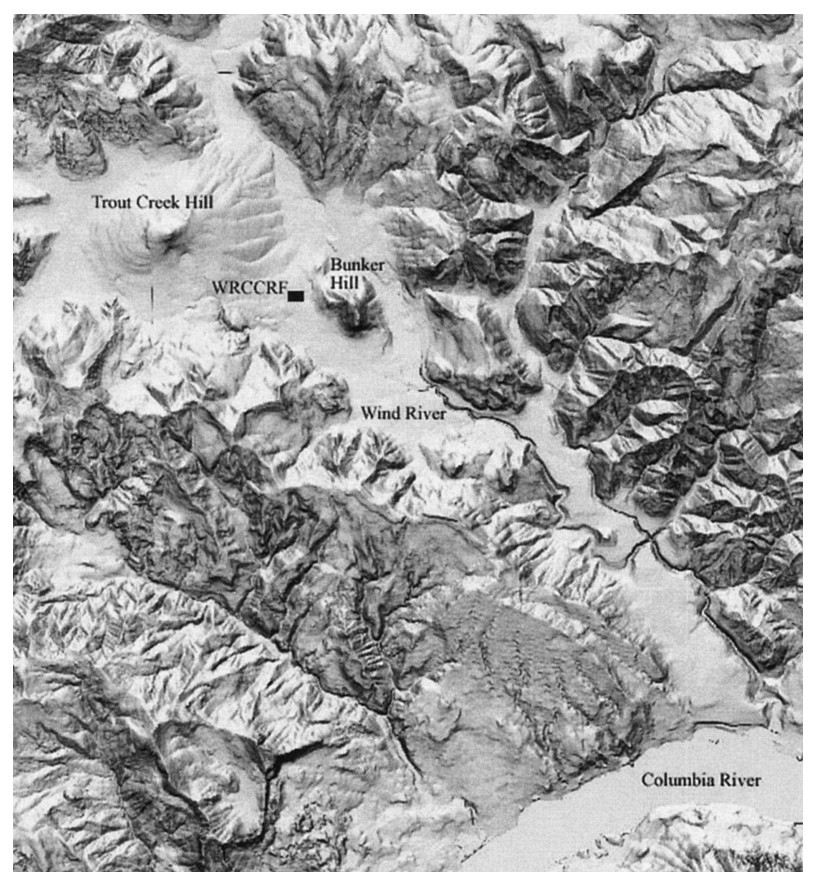

Figure 2. Area relief map of the Wind River Valley, including Trout Creek Hill (792-m elevation), Bunker Hill (636-m elevation), Wind River Canopy Crane Research Facility (WRCCRF, 371-m elevation), and the Columbia River (Lake Bonneville) (31-m elevation). The Wind River valley bottom bedrock is composed of lava flows from Trout Creek Hill, a Quaternary volcano approximately 340,000 years old. Bunker Hill is composed of Miocene gabbro intrusive rock underlain by volcanoclastic deposits of Miocene/Oligocene age.

the range due to orographic lift; the rapid increase with elevation on the western slopes is mirrored by a strong rain-shadow effect on the eastern slopes.

The Columbia River Gorge provides a natural pathway for the movement of air masses and organisms between the moist, moderate maritime environment west of the Cascade Range and the arid, more extreme continental environment east of the range. This circumstance results in some distinctive climatic events (Lawrence 1939). For example, the dominant westerly, year-around winds that are associated with mild marine air masses are occasionally interspersed by periods with strong easterly winds that bring dry cold (in winter) or hot (in summer) continental air from the interior. In addition, periodic collisions between Pacific storms and cold continental air result in severe ice, rain-on-snow, and snow storms.

The Wind River old-growth forest is located within the Wind River valley on gentle topography (less than 10\% slope) between two major topographic features-Trout Creek Hill and Bunker Hill (Figure 2). The crane and WRCCRF 4-ha plot are actually located on the southeastern foot of Trout Creek Hill (Figure 2), a shield volcano with a summit of 792-m elevation. Bunker Hill (636-m elevation) is a prominent steep-sided feature about $1 \mathrm{~km}$ to the southeast that affects the crane site by delaying direct sunlight for an hour or so in the morning and by providing some protection from east winds. The walls of Wind River valley itself rise approximately $1500 \mathrm{~m}$ above the valley floor, with the nearest located approximately $2 \mathrm{~km}$ to the south. The crane facility is located near the subtle divide between the Wind River and Trout Creek, a major tributary of the Wind River. The location of the forest near the divide between two watersheds limits the extent of soil water available to the site and contributes to dry soils during summer. Cold air drainage is primarily from the north, as higherelevation hills contribute cooling. The site is protected from severe windstorms, which come primarily from the west due to the north-south orientation of the valley bottom.

There have been significant human impacts on environmental conditions of the Wind River oldgrowth forest. The most important was the clearing of the forest and establishment of tree seedling nursery fields along the southern boundary of the RNA in the mid-1980s. This resulted in creation of a sharp, high-contrast edge 50-60 $\mathrm{m}$ high. The microclimatological consequences of this edge have been documented by Chen and colleagues (1992, 1993a, 1993b). Edge influences were found to extend into the forest for $200 \mathrm{~m}$. The crane is located approximately $500 \mathrm{~m}$ from this edge and, therefore, is not strongly impacted. However, the proximity to the fields does appear to affect some vertebrate species, such as elk, which bed in the old growth and feed in the fields. The influence of this edge on meteorologic conditions and the eddy-flux stations is discussed elsewhere (Paw U and others 2004). The 80-year-old Douglas-fir forest $500 \mathrm{~m}$ to the north of the crane site was logged around 1920 and was thinned in the early 1990s, but still provides a nearly intact buffer for the natural area and crane facility.

\section{Climate}

The Wind River old-growth forest climate summary is based on the 1978-98 National Oceanographic and Atmospheric Administration (NOAA) National Climate Data Center climate data (www.ncdc.noaa.gov) collected at the Carson National Fish Hatchery (US Fish and Wildlife Service) located $5 \mathrm{~km}$ north of the WRCCRF. Annual precipitation has historically averaged $2223 \mathrm{~mm} \mathrm{y}^{-1}$ $(\mathrm{SD}=5.7)$, with only about $5 \%$ falling during 


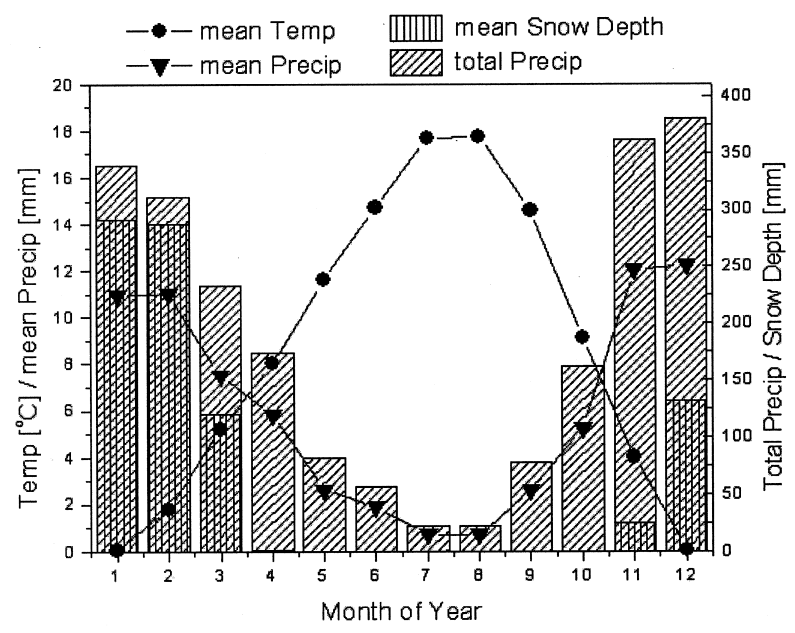

Figure 3. Climate regime from 1978 to 1998 for average monthly air temperature and average monthly precipitation, and total precipitation and snowpack (depth). Data were collected at the Carson National Fish Hatchery (www.ncdc.noaa.gov) located approximately $5 \mathrm{~km}$ north of the Wind River old-growth forest.

June, July, and August (Figure 3). This summer drought is an important characteristic of Pacific Northwest climate because it profoundly reduces summertime tree growth (Franklin and Waring 1980). Much of the winter precipitation falls as snow, and snowpack (depth) is over $100 \mathrm{~mm}$ during December, January, February, and March (Figure 3). Average annual air temperature was $8.7^{\circ} \mathrm{C}(\mathrm{SD}=6.5)$. Average monthly air temperature in January was $0.1^{\circ} \mathrm{C}(\mathrm{SD}=2.3)$, while average monthly air temperature in July was $17.7^{\circ} \mathrm{C}$ $(\mathrm{SD}=1.7)$.

The Wind River old-growth forest is in the transient snow zone of the Cascade Mountains, where rain-on-snow, freezing-rain, and graupel events are common. The importance of being in this transitional zone of winter climate cannot be overstated. The heavy buildup of wet snow on tree branches has a major influence on branch and bole breakage. For example, over $50 \%$ of the western hemlock trees in the crane site have evidence of leader and bole breakage. The deep, complex structured canopy is expected to play a major role in modifying the amount and timing of snowmelt runoff in this zone; old-growth forests reduce the peak flows associated with rain-on-snow events compared with cleared or very young forests (Harr 1986).

\section{Geology and Local Geography}

The Wind River valley is characterized by volcanic rocks and deposits of Miocene/Oligocene and
Quaternary age as well as intrusive rocks of Miocene age (Walsh and others 1987). Further geological information on the area can be found in Wise (1961, 1970), Hammond (1980), and Hammond and Korosec (1983). Although glacial deposits dated at more than 38,000 years before present have been identified in the region, details of glaciation are not well understood. Trout Creek Hill (Figure 2), the geologic feature on which the old-growth forest developed, is a Quaternary volcano approximately 340,000 years old. A cinder cone and lava tunnels are located at the summit. Dark-gray olivine basalt flowed from Trout Creek Hill (and possibly other vents) down the Wind River Valley in a series of intracanyon lava flows that reached the Columbia River (Walsh and others 1987; Woodfin and others 1987). These flows make up the bedrock that underlies the research site, as well as much of the valley floor. Bunker Hill is a prominent landform composed of Miocene gabbro intrusive rock underlain by volcanoclastic deposits of Miocene/Oligocene age.

The old-growth forest and crane site are located on an alluvial fan from Trout Creek Hill (Figure 2). The fan is slightly dissected by small drainages. Total relief across the crane circle is about $10 \mathrm{~m}$, with the lowest areas on the north and east and the highest on the west and south. An ephemeral stream runs through the crane circle about $30 \mathrm{~m}$ north of the crane. The creek is most deeply incised (about $2 \mathrm{~m}$ ) on the west. After leaving the crane circle, the stream flows into a forested wetland to the northeast of the crane. The wetland is located at the base of Bunker Hill and drains $2 \mathrm{~km}$ to the north (as Cold Creek) into Wind River.

\section{SoILS}

The soils are classified as medial, mesic, Entic Vitrands (Stabler Series, www.statlab.iastate.edu/ cgi-bin/osd/osdname.cgi). These soils are deep, well drained, generally stone free, and medium textured. The parent material is air-deposited, mixed volcanic tephra, of relatively recent origin (between 3500 and 12,000 years before present). A typical soil profile has a mull forest floor (average depth, $6 \mathrm{~cm} ; \mathrm{SD}=2.1 ; n=74$ ) above the mineral soil. The surface mineral layer is generally $45-\mathrm{cm}$ thick, dark yellowish brown shotty loam with approximately $5 \%-8 \%$ clay content. Volcanic material, ranging from 2 to $10 \mathrm{~mm}$ in size, accounts for $40 \%-50 \%$ by volume of the upper soil. The subsoil is commonly 45 - to $110-\mathrm{cm}$-deep, brown or yellowish brown silt to clay loam. The soil from 110 to 
Table 1. Concentrations of Carbon ( $\mathrm{g} \mathrm{C} \mathrm{kg}^{-1}$ Dry Soil) and Nitrogen ( $\mathrm{g} \mathrm{N} \mathrm{kg}^{-1}$ Dry Soil) and C: $\mathrm{N}$ Ratios in the Forest Floor and Soils from the Wind River Canopy Crane Research Facility 4-ha Plot

\begin{tabular}{|c|c|c|c|}
\hline Component & Carbon $\mathrm{g} \mathrm{kg}^{-1}$ & Nitrogen $\mathrm{g} \mathrm{kg}^{-1}$ & $\mathrm{C} / \mathrm{N}$ \\
\hline \multicolumn{4}{|l|}{ Forest floor } \\
\hline Oi & $452.9(10.2)$ & $8.0(0.4)$ & $59.7(3.5)$ \\
\hline Oe and Oa & $436.6(11.8)$ & $9.4(0.4)$ & $48.56(2.6)$ \\
\hline \multicolumn{4}{|l|}{ Soil } \\
\hline $0-10 \mathrm{~cm}$ & $52.6(3.7)$ & $1.9(0.1)$ & $28.0(1.2)$ \\
\hline $10-20 \mathrm{~cm}$ & $33.8(2.1)$ & $1.4(0.1)$ & $24.6(1.1)$ \\
\hline
\end{tabular}

$130 \mathrm{~cm}$ in depth is yellowish brown to strong brown massive clay loam. Some soil profiles exhibit up to $15 \%$ pumice gravels and coarse sand in lower soil layers. Abrupt depositional discontinuities are encountered at the lower depths that contain large amounts of gravels and cobbles, some of which are waterworn. Plant roots are concentrated above $50 \mathrm{~cm}$ in soil profiles; however, roots as deep as $2.05 \mathrm{~m}$ have been observed in younger forests growing on nearly identical soils (T. Hinckley personal communication). Many coarse roots of Douglas-fir extend to depths greater than $1.0 \mathrm{~m}$. Tip-up mounds of windthrown western hemlock trees typically have a classic flat root plate indicative of shallow rooting.

The mineral soils have a low bulk density, characteristic of Andisols with high organic matter content (Brady and Weil 1998; Cromack and others 1999). Bulk density of the top $20 \mathrm{~cm}$ of soil ranged from 0.70 to $0.92 \mathrm{~g} \mathrm{~cm}^{-3}$, increasing with depth. Soil pH (water to soil, 2:1) ranged from 4.9 to 5.7, values typical for Douglas-fir forests in this region [for example, see Heilman (1981)]. Organic matter contents (calculated as percent total C/0.58) ranged from $4.6 \%$ to nearly $10 \%$. Values for carbon (C) and nitrogen $(\mathrm{N})$ concentrations of the forest floor and mineral soil (Table 1) are comparable to most other similar forests in the region [for example, see Youngberg (1966) and Means and others (1992)] and are generally in the midrange for forest soils in the region. Based on 499 soil pedons in western Oregon, soil C for the upper $20 \mathrm{~cm}$ averaged $6.5 \mathrm{~kg}$ $\mathrm{m}^{-2}$ (range, 0.9-24) (Homan and others 1995), whereas the canopy crane site has $9.7 \mathrm{~kg} \mathrm{~m}^{-2}$ in the upper $20 \mathrm{~cm}$ of soil. In another study of soils under four Douglas-fir-western hemlock forests (Radwan 1992), N concentrations in the forest floor (Oi, Oe, and $\mathrm{Oa}$ ) averaged from $0.78 \%$ to $1.06 \%$, while $\mathrm{N}$ content of the upper $20 \mathrm{~cm}$ of soil ranged from $0.09 \%$ to $0.46 \%$. The forest floor values of the WRCCRF 4-ha plot fall within these ranges
(Table 1). The soil concentrations are reflective of the less than $2.00-\mathrm{mm}$ portion of soil, although the larger tephra (mentioned previously) contained both $\mathrm{C}$ and $\mathrm{N}$ concentrations approaching those of the less than 2.00-mm fractions of soil (Cromack and others 1999). These large particles are known to have a high retention of phosphorus and absorptivity of organic C and N (Brady and Weil 1996).

The pattern of $\mathrm{C}$ and $\mathrm{N}$ across the research site reflects the microsite soil heterogeneity of the oldgrowth forest system, a result of windthrow mounds and large, buried, coarse woody debris. Coarse woody debris constitutes over $93 \mathrm{Mg} \mathrm{C} \mathrm{ha}^{-1}$ (Harmon and others 2004). The northeast quadrant of the WRCCRF 4-ha plot is seasonally inundated by water, and this results in a greater storage of $C$ and $\mathrm{N}$, presumably due to the seasonal anaerobic conditions and reflected in seasonal patterns of $\mathrm{CO}_{2}$ efflux (J. Klopatek unpublished). Since December 1998, the water table has been monitored weekly with four peziometers running across the slope at the site. In the downhill (northeast quadrant of the WRCCRF 4-ha plot) well, from December through March the water table is highest and varies from 50 to $30 \mathrm{~cm}$ below the surface. In contrast, from September through October the water table is lowest and varies from 200 and $235 \mathrm{~cm}$ below the surface. In the uphill (southwestern quadrant of the WRCCRF 4-ha plot) well, from December through March the water table varies from 206 to $188 \mathrm{~cm}$ below the surface, whereas from May through October the water table drops below the well at $234 \mathrm{~cm}$.

\section{UNDERSTORY VEgETATION}

The WRCCRF plot is mapped on the border of the Western Hemlock/Salal (Gautheria shallon)-Western Hemlock/Oregon grape (Berberis nervosa)/Salal plant association complex and Pacific Silver Fir 


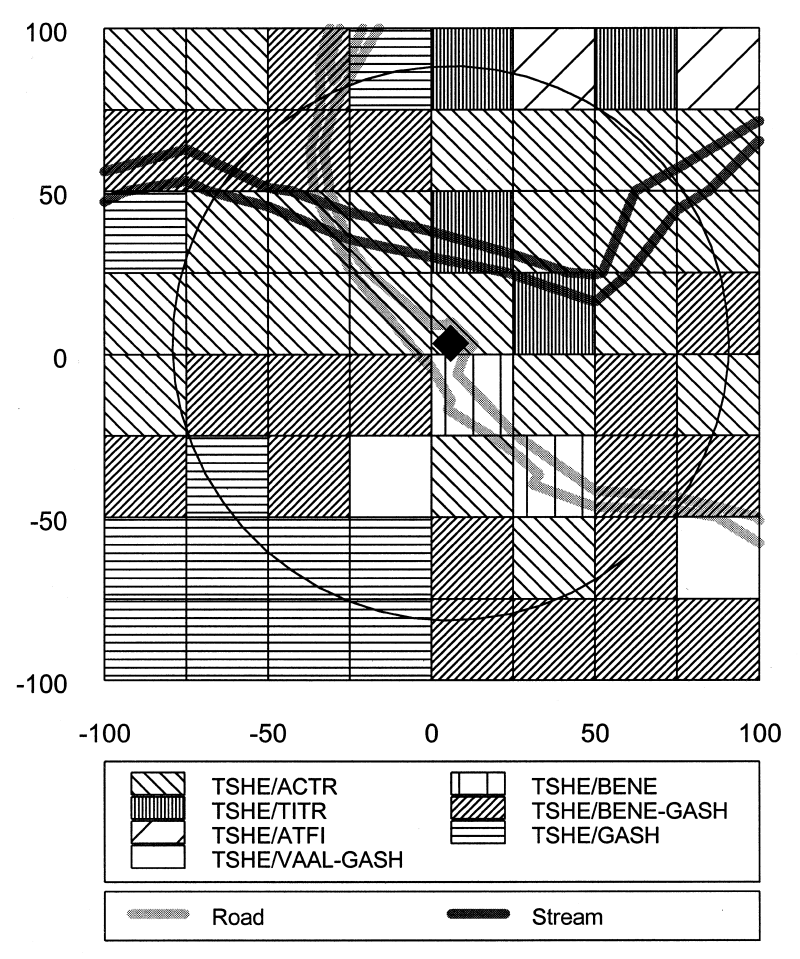

Figure 4. Plant associations of the Wind River Canopy Crane Research Facility 4-ha crane plot. Each square is $25 \times 25 \mathrm{~m}$. The circle represents the swing of the crane jib (2.3 ha), whereas the black square, just off center, is the crane tower location. An ephemeral stream runs through the northern portion of the plot, and an old logging road (about $4 \mathrm{~m}$ wide) runs through the plot. Plant associations, from wet-site to dry-site indicators, are TSHE/ATFI, Tsuga heterophyllalAthyrium filix-femina (Western Hemlock/Lady Fern) (2 subplots); TSHE/TITR, T. heterophyllal Tiarella trifoliata (Western Hemlock/Foamflower) (4 subplots); TSHE/VAAL-GASH, T. heterophylla/Vaccinium alaskaense-Gaultheria shallon (Western Hemlock/Alaska Huckleberry-salal) (2 subplots); TSHE/ACTR, T. heterophylla/Achlys triphylla (Western Hemlock/Vanilla Leaf) (23 subplots); TSHE/BENE, T. heterophylla/Berberis nervosa (Western Hemlock/Oregon Grape) (2 subplots); TSHE/ BENE-GASH, T. heterophylla/B. nervosa/G. shallon (Western Hemlock/Oregon Grape-Salal) (20 subplots), and TSHE/GASH, T. heterophylla/G. shallon (Western Hemlock/Salal) (1 1 subplots).

(Abies amabilis)/Salal plant association (Meyers and Fredricks 1993). These plant associations, characterized by a dominance of Salal and Oregon grape, are very widespread in the southern Cascades of Washington, especially on ridges and upper slopes, and are characterized by moderate to low productivity, with dry well-drained soils (Franklin and Dyrness 1973; Topik and others 1986). However, the abundance of winter snowpack, and a welldeveloped component of Pacific silver fir indicate that this site exhibits environmental conditions approaching that of the Pacific Silver Fir Zone (Brockway and others 1983).

Understory vegetation has an estimated leaf-area index (LAI) of 1.69 (Thomas and Winner 2000), which is $20 \%$ of the estimated total stand LAI of 8.61. We quantified understory plant cover and frequency on sixty-four $25-\times 25-\mathrm{m}$ subplots in the WRCCRF 4-ha study area (Table 2). To date, we have identified 68 vascular plant species (Tables 2 and 3), whereas Kemp and Schuller (1982) identified 178 species of vascular plants in the T. T. Munger RNA, which includes wetlands to the east of the crane site. Among the vascular plants, 33 plant families are represented, 18 by only one species, and 7 by two species. Dominant plant families include Ericaceae (8 sp.), Liliaceae (7 sp.), Pinaceace (6 sp.), Polypodiaceae (5 sp.) and Roseaceae (5 sp.). Prominence values (PVs), determined by multiplying the average percent cover by the average percent frequency, indicate the dominant understory species are vine maple (Acer circinatum, PV 25.5), salal (PV 16.0), Oregon grape (PV 14.2), vanilla leaf (Achlys triphylla, PV 4.4), red huckleberry (Vaccinium parvifolium, PV 4.2), inside-out flower (Vancouvaria hexandra, PV 1.4), bracken fern (Pteridium aquilinum, PV 1.4), twinflower (Linnaea borealis, PV 1.1), and bear grass (Xerophyllum tenax, PV 1.0) (Table 3). No other plant species rated a PV 1 or above.

A total of seven plant associations were keyed from the 64 subplots (Figure 4) using a report by Topik and colleagues (1986). These include, from wet-site to dry-site indicators, Western Hemlock/ Lady Fern (Athyrium filix-femina) (two subplots), Western Hemlock/Foamflower (Tiarella trifoliata) (four subplots), Western Hemlock/Alaska Huckleberry (Vaccinium alaskaense)-salal (two subplots), Western Hemlock/Vanilla Leaf (23 subplots), Western Hemlock/Oregon Grape (two subplots), Western Hemlock/Oregon Grape-Salal (20 subplots), and Western Hemlock/Salal (11 subplots) (Figure 4). This diversity of habitat types at the subplot level reflects the diversity of microhabitat across the site. The wetter north and northeast portions of the plot keyed to wetter plant associations characterized by lady fern, foamflower, and vanilla leaf. The uphill portion of the plot is characterized by salal and Oregon grape.

\section{Forest Tree Characterization}

In the WRCCRF 4-ha plot directly under and around the canopy crane, all trees $5 \mathrm{~cm}$ or larger have been tallied, measured, and mapped (Table 3 
Table 2. Vascular Plant Species in the Understory of the Wind River Old-growth Forest

\begin{tabular}{|c|c|c|c|c|c|}
\hline Species/Form & Scientific Name & Family & Ave. \% Cover & Frequency & PV \\
\hline \multicolumn{6}{|l|}{ Shrubs } \\
\hline Vine maple & Acer circinatum & Aceraceae & 26.7 & 95 & 25.5 \\
\hline Salal & Gaultheria shallon & Ericaceae & 16.0 & 100 & 16.0 \\
\hline Oregon grape & Berberis nervosa & Berberidaceae & 14.2 & 100 & 14.2 \\
\hline Red huckleberry & Vaccinium parvifolium & Ericaceae & 4.4 & 97 & 4.2 \\
\hline Baldhip rose & Rosa gymnocarpa & Rosaceae & 0.7 & 55 & 0.4 \\
\hline $\begin{array}{l}\text { Alaska } \\
\text { huckleberry }\end{array}$ & $V$. alaskaense & Ericaceae & 0.6 & 31 & 0.2 \\
\hline Beaked hazelnut & Corylus cornuta & Betulaceae & 0.4 & 28 & 0.1 \\
\hline Cascara & Rhamnus purshiana & Rhamnaceae & 0.2 & 16 & 0.03 \\
\hline Snowberry & Symphoricarpos albus & Caprifoliaceae & 0.1 & 8 & 0.01 \\
\hline $\begin{array}{l}\text { Black } \\
\text { huckleberry }\end{array}$ & V. membranaceum & Ericaceae & 0.1 & 6 & 0 \\
\hline Blackcap & Rubus leucodermis & Rosaceae & 0.03 & 2 & 0 \\
\hline Honeysuckle & Lonicera ciliata & Caprifoliaceae & 0.02 & 2 & 0 \\
\hline $\begin{array}{l}\text { Salmonberry } \\
\text { Herbs }\end{array}$ & R. spectabilis & Rosaceae & 0.02 & 2 & 0 \\
\hline Vanilla leaf & Achlys triphylla & Berberidaceae & 4.4 & 100 & 4.4 \\
\hline Inside-out flower & Vancouveria hexandra & Berberidaceae & 1.6 & 88 & 1.4 \\
\hline Twinflower & Linnaea borealis & Caprifoliaceae & 1.3 & 88 & 1.1 \\
\hline Bear grass & Xerophyllum tenax & Liliaceae & 1.4 & 73 & 1.0 \\
\hline Trillium & Trillium ovatum & Liliaceae & 1.0 & 95 & 0.9 \\
\hline $\begin{array}{l}\text { Queen cup bead } \\
\text { lily }\end{array}$ & Clintonia uniflora & Liliaceae & 0.9 & 88 & 0.8 \\
\hline $\begin{array}{l}\text { Trailing yellow } \\
\text { violet }\end{array}$ & Viola sempervirens & Violaceae & 0.9 & 86 & 0.8 \\
\hline $\begin{array}{l}\text { Rattlesnake } \\
\text { plantain }\end{array}$ & Goodyera oblongifolia & Orchidaceae & 0.7 & 70 & 0.5 \\
\hline Hooker's fairybell & Disporum hookeri & Liliaceae & 0.6 & 61 & 0.4 \\
\hline $\begin{array}{l}\text { Three-leaved } \\
\text { Anemone }\end{array}$ & Anemone deltoidea & Ranunculaceae & 0.6 & 59 & 0.4 \\
\hline Foamflower & Tiarella trifoliata & Saxifragaceae & 0.6 & 53 & 0.3 \\
\hline $\begin{array}{l}\text { Starry } \\
\text { Solomen pluume }\end{array}$ & Smilacena stellata & Liliaceae & 0.6 & 53 & 0.3 \\
\hline Prince's pine & Chimaphila umbellata & Pyrolaceae & 0.5 & 52 & 0.3 \\
\hline $\begin{array}{l}\text { False lily of the } \\
\text { valley }\end{array}$ & Maianthemum dilatatum & Liliaceae & 0.3 & 30 & 0.1 \\
\hline $\begin{array}{l}\text { Trailing } \\
\text { blackberry }\end{array}$ & Rubus ursinus & Rosaceae & 0.3 & 30 & 0.1 \\
\hline Starflower & Trientalis latifolia & Primulaceae & 0.3 & 30 & 0.1 \\
\hline Pathfinder & Adenocaulon bicolor & Asteraceae & 0.3 & 27 & 0.1 \\
\hline Bedstraw & Galium triflorum & Rubiaceae & 0.2 & 20 & 0.04 \\
\hline $\begin{array}{l}\text { Bunchberry } \\
\text { dogwood }\end{array}$ & Cornus canadensis & Cornaceae & 0.2 & 16 & 0.03 \\
\hline Twisted stalk & Streptopus amplexifolius & Liliaceae & 0.2 & 16 & 0.02 \\
\hline Baneberry & Actaea rubra & Ranunculaceae & 0.1 & 11 & 0.01 \\
\hline $\begin{array}{l}\text { Menzies' } \\
\text { pipissewa }\end{array}$ & Chimaphila menziesii & Pyrolaceae & 0.05 & 5 & 0 \\
\hline Dogbane & $\begin{array}{l}\text { Apocynum } \\
\text { Androsaemifolium }\end{array}$ & Apocynaceae & 0.03 & 3 & 0 \\
\hline Wild ginger & Asarum caudatum & Aristolochiaceae & 0.03 & 3 & 0 \\
\hline Hairbell & Campanula scouleri & Campanulaceae & 0.03 & 3 & 0 \\
\hline Hawksbeard & Hieracium albiflorum & Asteraceae & 0.03 & 3 & 0 \\
\hline Veronica & Veronica americana & Scrophulariaceae & 0.02 & 2 & 0 \\
\hline
\end{tabular}


Table 2. Continued

\begin{tabular}{|c|c|c|c|c|c|}
\hline Species/Form & Scientific Name & Family & Ave. \% Cover & Frequency & PV \\
\hline \multicolumn{6}{|l|}{ Ferns } \\
\hline $\begin{array}{l}\text { Bracken } \\
\text { fern }\end{array}$ & Pteridium aquilinum & Polypodiaceae & 1.5 & 91 & 1.4 \\
\hline Deer fern & Blechnum spicant & Polypodiaceae & 2.1 & 38 & 0.8 \\
\hline Sword fern & Polysticum munitum & Polypodiaceae & 0.6 & 42 & 0.3 \\
\hline Lady fern & Athyrium felix-femina & Polypodiaceae & 0.5 & 25 & 0.1 \\
\hline Sierra wood fern & Thelypteris nevadensis & Polypodiaceae & 0.4 & 19 & 0.1 \\
\hline $\begin{array}{l}\text { Running } \\
\text { clubmoss }\end{array}$ & Lycopodium clavatum & Lycopodiaceae & 0.1 & 8 & 0.01 \\
\hline \multicolumn{6}{|l|}{ Graminoids } \\
\hline Woodrush & Luzula campestris & Juncaceae & 0.03 & 3 & 0 \\
\hline Nodding trisetum & Trisetum cernuum & Poaceae & 0.02 & 2 & 0 \\
\hline \multicolumn{6}{|c|}{ Nonchlorophyllous ericad's } \\
\hline Indian pipe & Monotropa uniflora & Ericaceae & 0.05 & 5 & 0 \\
\hline Candystick & Allotropa virgata & Ericaceae & 0.02 & 2 & 0 \\
\hline Pinesap & Hypopitys monotropa & Ericaceae & 0.02 & 2 & 0 \\
\hline Pinedrops & Pterospora andromedea & Ericaceae & 0.02 & 2 & 0 \\
\hline \multicolumn{6}{|l|}{ Nonnative weeds } \\
\hline Plantain & Plantago major & Plantaginaceae & 0.1 & 6 & 0 \\
\hline Self-heal & Prunella vulgaris & Labiatae & 0.05 & 5 & 0 \\
\hline Pearly everlasting & Anaphalis margaritacea & Asteraceae & 0.02 & 2 & 0 \\
\hline White clover & Trifolium repens & Fabaceae & 0.02 & 2 & 0 \\
\hline Festuca & Festuca pratensis & Poaceae & 0.02 & 2 & 0 \\
\hline
\end{tabular}

Data are based on sixty-four $25 \times 25-m$ subplots that make up the Wind River Canopy Crane Research Facility 4 -ha plot. Ave. \% Cover is the mean cover estimated on all 64 subplots. Frequency is the percentage of subplots a plant species occurred in. PV, prominence value (Ave. \% cover * frequency).

and Figure 5). The forest has eight coniferous species, including Douglas-fir, western hemlock, western red cedar (Thuja plicata), Pacific yew (Taxus brevifolia), Pacific silver fir, noble fir (Abies procera), grand fir (Abies grandis), western white pine (Pinus monticola), and two small stature angiosperms, cascara (Rhamnus purshiana) and Pacific dogwood (Cornus nuttallii). Red alder (Alnus rubra) occurs in some canopy gaps along the ephemeral stream. Here, the 1999 basal area of conifers is $82.9 \mathrm{~m}^{2}$ $\mathrm{ha}^{-1}$, falling in the midrange $\left(50-129 \mathrm{~m}^{2} \mathrm{ha}^{-1}\right)$ of 450- to 500-year-old stands reported by Franklin and Waring (1980) in the Pacific Northwest. Average density of all trees is 427 stems ha ${ }^{-1}$. The majority of trees are western hemlock (224.0 trees $\mathrm{ha}^{-1}$ ); however, Douglas-fir is the dominant species with respect to basal area $\left(35.4 \mathrm{~m}^{2} \mathrm{ha}^{-1}\right)$, followed by western hemlock $\left(26.9 \mathrm{~m}^{2} \mathrm{ha}^{-1}\right)$ and western red cedar $\left(16.5 \mathrm{~m}^{2} \mathrm{ha}^{-1}\right)$. Average height of Douglas-fir is $52.0 \mathrm{~m}$ (Figure 5), with the tallest tree being $64.6 \mathrm{~m}$, much less than the maximum heights of Douglas-fir, which often reach 70-80 m in more favorable sites (Franklin and Waring 1980). Western hemlock height averages $19.0 \mathrm{~m}$, with the tallest tree being $55.4 \mathrm{~m}$. This is in the range of maximum attainable heights $(50-65 \mathrm{~m}$ ) reported by Franklin and Waring (1980). The vertical structure of the forest (Figure 1) is described in detail by Parker and colleagues (2004). The height and diameter distribution of Douglas-fir indicate a classic shade-intolerant cohort of trees that are not being replaced by reproduction (Figure 5). Western hemlock, western red cedar, Pacific yew, and Pacific silver fir are shade tolerant and reproducing well (Figure 5).

\section{Disturbance and Dynamics}

The primary disturbance regime for Douglas-fir forests in this region is catastrophic, stand-replacement (high to moderate severity) fire, which appears to have occurred in the past at return intervals of 300-650 years (Hemstrom and Franklin 1982; Agee 1991; Gray and Franklin 1997). The Wind River old-growth forest most likely originated after a high-severity fire, or series of fires, about 500 years before present. The Douglas-fir trees, estimated to be 375-500 years old (J. Franklin personal communication), were dated by counting growth rings on stumps surrounding the $\mathrm{T}$. T. Munger RNA. We have cored 17 large-diameter western hemlock trees within the old-growth 
Table 3. Conifer Tree Species ${ }^{a}$ in the Wind River Old-growth Forest

\begin{tabular}{|c|c|c|c|c|c|}
\hline Tree species & Trees ha $\mathrm{ha}^{-1}$ & $\begin{array}{l}\text { Standing } \\
\text { Dead ha }^{-1}\end{array}$ & $\begin{array}{l}\mathrm{DBH}^{\mathrm{b}}(\mathrm{cm}) \\
(\text { mean) }\end{array}$ & $\begin{array}{l}\text { Height } \\
\text { (m) (mean) }\end{array}$ & $\begin{array}{l}\text { Basal area } \\
\mathrm{m}^{2} \mathrm{ha}^{-1}\end{array}$ \\
\hline Abies amabilis & 47.0 & 9.2 & 12.2 & 8.5 & 1.2 \\
\hline Abies grandis & 4.5 & 5.0 & 51.3 & 39.1 & 1.0 \\
\hline Abies procera & 0.5 & 0.0 & 49.8 & 32.3 & 0.1 \\
\hline Pinus monticola & 0.5 & 4.0 & 48.0 & 32.1 & 0.1 \\
\hline $\begin{array}{l}\text { Pseudotsuga } \\
\text { menziesii }\end{array}$ & 35.0 & 54.5 & 111.0 & 52.0 & 35.4 \\
\hline Taxus brevifolia & 85.8 & 15.8 & 13.8 & 6.2 & 1.7 \\
\hline Thuja plicata & 30.0 & 3.5 & 68.6 & 29.0 & 16.5 \\
\hline $\begin{array}{l}\text { Tsuga } \\
\text { heterophylla }\end{array}$ & 224.0 & 18.0 & 29.9 & 19.0 & 26.9 \\
\hline Total conifers & 427.3 & 110.0 & 34.2 & 19.2 & 82.9 \\
\hline
\end{tabular}

Data are $\mathrm{ha}^{-1}$, averaged from the Wind River Canopy Crane Research Facility 4-ha plot. Standing dead tree minimum height, 1.37 m. Three angiosperm tree species (Cornus nuttalii,Alnus rubra, and Rhamnus purshiana) are also present, but not abundant.

${ }^{a}$ With DBH greater than $5 \mathrm{~cm}$.

${ }^{b} \mathrm{DBH}$, diameter at breast height.

stand, and none of them are over 300 years of age. Douglas-fir probably dominated the young forest for the first 200 years, after which the shade-tolerant western hemlock and western red cedar were recruited into the understory.

A series of mortality strips and growth plots were installed in the T. T. Munger RNA in 1947 (King 1961) and provide information on the recent disturbance dynamics of this 500-year-old forest. DeBell and Franklin (1987) and Franklin and DeBell (1988) have analyzed 36 years of this record (1947-83, collected in 6-year intervals) for tree population change, growth, and mortality. The annual rate of mortality for all trees during this period was $0.75 \%$, with $22 \%$ of the original stems dying. Western hemlock, western red cedar, and Pacific silver fir, all shade-tolerant species, were recruited into the stand so that the total number of live trees $\mathrm{ha}^{-1}$ was maintained $(1947=479.5$ tree $\mathrm{ha}^{-1} ; \quad 1983=443.6$ trees $\left.\mathrm{ha}^{-1}\right)$. Douglas-fir accounted for $33 \%$ of the volume $\left(\mathrm{m}^{3} \mathrm{ha}^{-1}\right)$ growth yet nearly $50 \%$ of the mortality volume. Western hemlock accounted for $50 \%$ of the volume growth but only $28 \%$ of the mortality volume. Pacific silver fir increased in the lower canopy, accounting for $60 \%$ of the small tree ingrowth. The Douglas-fir trees are slowly dying out of the stand because there is no reproduction of this shade-intolerant species in the understory. The extinction of Douglas-fir is predicted in 740 years at the current rate of mortality (Franklin and DeBell 1988). Four canopy processes are responsible for the long-term survival of individual Douglas-fir trees (Ishii and Ford 2002; Ishii and others 2000a, 2000b). These include ver- tical stratification (Douglas-fir dominates the upper canopy), decreasing crown competition in the upper canopy, morphological acclimation (old Douglas-fir have a unique crown form and branching pattern that maintains efficient shoot and foliage display), and crown maintenance (epicormic branching at the twig, branch, and stem levels maintains foliage).

The 125-year age spread of the Douglas-fir trees is typical for stand initiation in the region. One reason may be reburns of areas that were originally catastrophically burned (Gray and Franklin 1997), although competition with shrubs and seed source may also play a role. Although reburns may occur, light ground fires within forests are rare, and there is no evidence in the T. T. Munger RNA that, once the forest stand was fully established, fire has occurred. Wind disturbance is common in the region, but catastrophic wind events are associated with forests on exposed westerly slopes and ridgetops whereas the Wind River old-growth forest is in a northsouth-oriented valley bottom, protected from the most severe wind effects coming from the coast.

Mortality in this forest is associated with unknown causes $(30 \%)$, windthrow $(23 \%)$, broken bole or top $(22 \%)$, mechanical snow damage $(10 \%)$, crushing $(7 \%)$, and insects and diseases $(6 \%)$ (Franklin and DeBell 1988). Windthrow events tend to be at the individual tree level and associated with root-rot and butt-rot fungi for uprooting and butt snap, as well as heart-rot fungi for stem breakage (Bible 2001). An episode of Douglasfir bark beetle (Dendroctonus pseudotsugae)-caused mortality was reported for the 1950s, and Franklin 


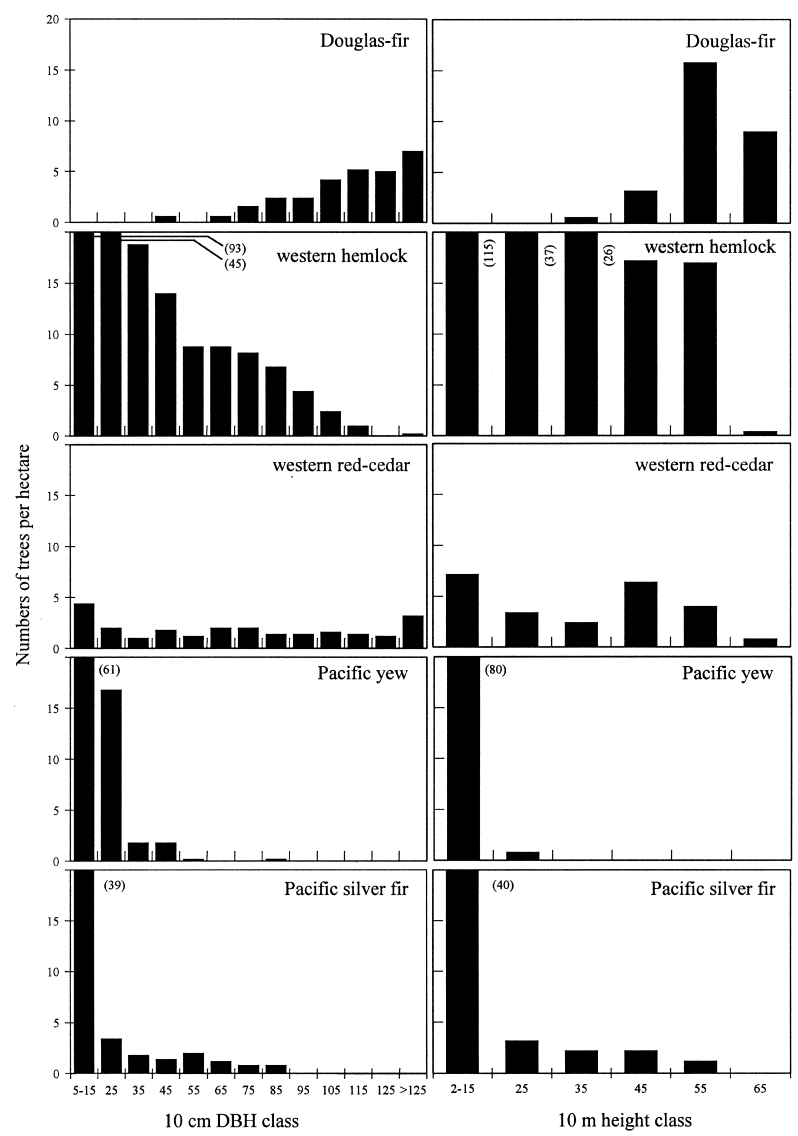

Figure 5. Tree diameter $[10-\mathrm{cm}$ diameter at breast height (DBH) classes] and height (10-m height classes) class distribution of major conifer tree species on the Wind River Canopy Crane Research Facility 4-ha crane plot. Data for trees is the average $\mathrm{ha}^{-1}$.

and DeBell feel that much of the unknown mortality of Douglas-fir may be associated with this beetle, in conjunction with root disease and other stressors such as drought. White pine blister rust (Cronartium ribicola), a nonnative disease, is associated with decline and mortality of western white pine, although mountain pine beetle (Dendroctonus ponderosae) may also play a role. Hemlock dwarf mistletoe (Arceuthobium tsugense) is common in the T. T. Munger RNA and may weaken and kill western hemlock (DeBell and Franklin 1987). It occurs over about 1 ha of the WRCCRF 4-ha plot in a distinct infection center (Mathiasen and Shaw 1998; Shaw and others 2000). Pacific silver fir mortality is associated with Armillaria root disease (Armillaria spp.), which is especially virulent on silver fir at the lower limits of the Pacific silver fir vegetation zone (G. MacDonald personal communication).

Herbivory (folivory) is estimated at less than $2 \% \mathrm{y}^{-1}$ for the canopy trees at the canopy crane site (Schowalter and Ganio 1998; Shaw and others unpublished). Defoliator outbreaks in oldgrowth Douglas-fir forests west of the Cascade crest are rare (Perry and Pitman 1983). Herbivory at Wind River is much greater in the understory, where an annual rate of $9.9 \%$ was documented for vine maple in 1999 (Braun and others 2002). Deer and elk also play a significant role in understory herbivory. We have observed considerable browsing by these animals on salal, huckleberries, vine maple, and bear grass, as well as small Pacific yew and western red cedar.

\section{Old-GROWTH Forests}

Characterizing a forest as "old growth" is important because of the theoretical and practical concepts concerning how stand age and productivity will influence carbon dynamics. Tree productivity, forest-stand productivity, and live-tree biomass accumulation all decline with age (Bond and Franklin 2002). Decreasing net primary productivity and increasing mortality account for the decline in live-tree biomass accumulation in Douglas-fir forests (Acker and others 2002). However, carbon dynamics also include total forest carbon accumulation (sequestration), which increases with stand age in the Pacific Northwest of North America (Janisch and Harmon 2002). Whether oldgrowth forests will function as a carbon sink or source to the atmosphere is a critical question asked in this special feature (Paw U and others 2004). Predicting carbon storage and exchange with the atmosphere at the landscape level requires scaling the various age classes and management regimes (Harmon 2001), and an important consideration includes the extent and distribution of old growth. Old-growth forests may currently occur on about 4.12 million ha in Washington, Oregon, and northern California (Bolsinger and Waddell 1991), although definitions vary and not all experts agree on this number (Margot and others 1991). This may be about $17 \%$ of the original old growth that occupied the region in the mid 1800s, although this is also debated (Margot and others 1991) and may by closer to $10 \%$.

Old-growth Douglas-fir forests are characterized by large, live old (175-350 years + ) trees, a deep $(50 \mathrm{~m}+)$ vertically continuous canopy, large snags, large logs on land, and large logs in streams (Franklin and others 1981; Franklin and Spies 1991). Old-growth forests retain nutrients; accumulate organic matter; reduce peak flows during rainfall runoff; are heterogeneous; provide optimum habitat for specialized vertebrates; have well- 


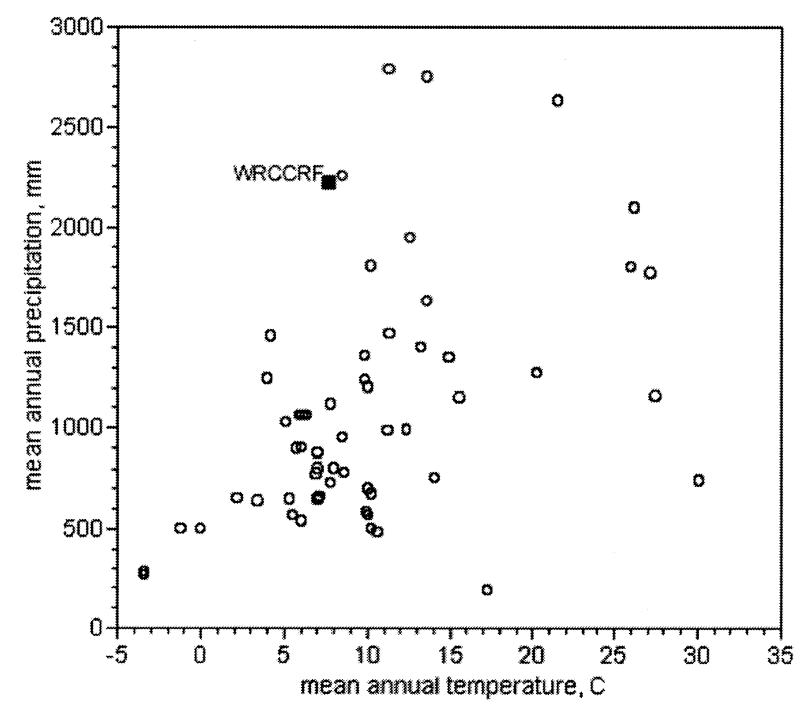

Figure 6. Mean temperature and precipitation for a global distribution of representative forests (circles) from the International Biological Program, Woodlands Dataset (DeAngelis and others 1981) (ORNL DAAC archive at www.ornl.gov). The Wind River Canopy Crane Research Facility (WRCCRF) site is added to this figure, located in the top left-hand corner as a solid square, to provide a reference for the global climatic regime of the site. The Wind River old-growth forest is at the extreme combination of cool and wet for sites summarized in this dataset.

developed understory vegetation; have a high diversity of arthropods, fungi, lichens, and bryophytes; and maintain high gross productivity, although mortality usually balances growth (Franklin and others 1981). A unique characteristic of Pacific Northwest old-growth forests is the long persistence of primary successional species, such as Douglas-fir and western white pine (Pinus monticola), which can live for 400-1000 years (Franklin 1988).

Structural features that define a forest as an oldgrowth Douglas-fir forest in western Washington and Oregon, on western hemlock sites, are 10-20 Douglas-fir trees larger than $80-\mathrm{cm}$ diameter at breast height $(\mathrm{DBH}) \mathrm{ha}^{-1}, 20$ trees of any species larger than 80-cm DBH ha ${ }^{-1}, 10-30$ shade-tolerant trees larger than $40-\mathrm{cm}$ DBH ha-1, 4-10 snags larger than $50-\mathrm{cm} \mathrm{DBH}$ and larger than $5 \mathrm{~m}$ tall $\mathrm{ha}^{-1}$, and a minimum log biomass of 30-34 tons $\mathrm{ha}^{-1}$ (Franklin and Spies 1991). The WRCCRF 4-ha plot averages 31.5 Douglas-fir ha ${ }^{-1}$ larger than 81cm DBH, 78.5 shade-tolerant-associated tree species (western hemlock, western red cedar, Pacific silver fir) $\mathrm{ha}^{-1}$ larger than $41-\mathrm{cm} \mathrm{DBH}, 59.5$ snags $\mathrm{ha}^{-1}$ larger than $51-\mathrm{cm}$ DBH (although we did not include minimum height of $5 \mathrm{~m}$ ), and log biomass is $93.9 \mathrm{Mg} \mathrm{ha}{ }^{-1}$. Therefore, the Wind River forest fits the structure-based definition of an old-growth forest.

\section{Global Context}

The International Biological Program, Woodlands Data Set (DeAngelis and others 1981), represents the range of mean annual rainfall and temperature conditions for forests throughout the globe. The Wind River old-growth forest lies at an extreme combination of cool and wet for sites summarized in this dataset (Figure 6). There are other colder forested sites but they are drier, and there are many warmer forested sites but they can be wetter. Structurally, the stand has one of the higher aboveground biomass numbers reported globally, although it is at the low end of the range for old-growth forests in the Pacific Northwest (Harmon and others 2004). The forest is characterized as a temperate coniferous seasonal rain forest due to the high rainfall $\left(2223 \mathrm{~mm} \mathrm{y}^{-1}\right)$, lat-

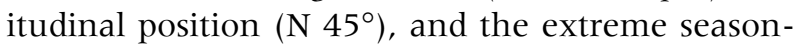
ality of the rainfall (less than 10\% during summer) (Schoonmaker and others 1997).

\section{ACKNOWLEDGEMENTS}

The Wind River Canopy Crane Research Facility is a cooperative scientific venture between the University of Washington, College of Forest Resources, USDA Forest Service Pacific Northwest Research Station, and the Gifford Pinchot National Forest. Joel Norgren and Ted Dyrness provided the soil profile descriptions of the T. T. Munger RNA and input on the soils section. Tom High also provided input on the soils section. Some of this work was supported by the Office of Science, Biological and Environmental Research Program (BER), US Department of Energy (DOE), through the Western Regional Center (WESTGEC) of the National Institute for Global Environmental Change (NIGEC) under Cooperative Agreement DE-FCO390ER61010. Any opinions, findings, and conclusions or recommendations expressed herein are those of the authors and do not necessarily reflect the view of DOE.

\section{REFERENCES}

Acker SA, Halpern CB, Harmon ME, Dyrness CT. 2002. Trends in bole biomass accumulation, net primary production and tree mortality in Pseudotsuga menziesii forests of contrasting age. Tree Physiol 22:213-7. 
Agee JK. 1991. Fire history of Douglas-fir forests in the Pacific Northwest. In: Ruggiero LF, Aubry KB, Carey AB, Huff MH, technical coordinators. Wildlife and vegetation of unmanaged Douglas-fir forests. General technical report PNW-GTR-285. Portland (OR): USDA Forest Service, Pacific Northwest Research Station. p 25-33.

Bible KJ. 2001. Long-term patterns of Douglas-fir and western hemlock mortality in the Cascade Mountains of Oregon and Washington [dissertation]. Seattle: University of Washington.

Bolsinger CL, Waddell KL. 1993. Area of old-growth forests in California, Oregon and Washington. Resource bulletin PNWRB-197. Portland (OR): USDA Forest Service, Pacific Northwest Research Station.

Bond BJ, Franklin JF. 2002. Aging in Pacific Northwest forests: a selection of recent research. Tree Physiol 22:73-6.

Brady NC, Weil RR. 1996. The nature and property of soils. Prentice Hall: EnglewoodCliffs (NJ).

Brockway DG, Topik C, Hemstrom MA, Emmingham WH. 1983. Plant association and management guide for the Pacific Silver Fir Zone, Gifford Pinchot National Forest. R6-Ecol-130a-1983. Portland (OR): USDA Forest Service, Pacific Northwest Research Station.

Braun DM, Runcheng B, Shaw DC, Van Scoy M. 2002. Folivory of vine maple in an old-growth Douglas-fir-western hemlock forest. Northwest Sci 76:315-21.

Chen J, Franklin JF, Spies TA. 1992. Vegetation responses to edge environments in old-growth Douglas-fir forests. Ecol Appl 2:387-96.

Chen J, Franklin JF, Spies TA. 1993a. An empirical model for predicting diurnal air-temperature gradients from clearcutforest edge into old-growth Douglas-fir forest. Ecol Modell 67:179-98.

Chen J, Franklin JF, Spies TA. 1993b. Contrasting microclimate patterns among clearcut, edge, and interior area of old-growth Douglas-fir forest. Agric For Meteorol 63:219-37.

Cromack K Jr, Miller RE, Helgerson OT, Smith RB, Anderson HW. 1999. Soil carbon and nutrients in a coastal Douglas-fir plantation with red alder. Soil Sci Soc Am J 63:232-9.

DeAngelis DL, Gardner RH, Shugart HH. 1981. Productivity of forest ecosystems studied during the IBP: the woodlands data set. In: Reichle DE editor. Dynamic properties of forests ecosystems. Cambridge: Cambridge University Press. p 567673.

DeBell DS, Franklin JF. 1987. Old-growth Douglas-fir and western hemlock: a 36-year record of growth and mortality. West J Appl For 2:111-4.

Franklin JF. 1972. Wind River Research Natural Area.Federal Research Natural Areas in Oregon and Washington: a guidebook for scientists and educators. Portland: Pacific Northwest Forest and Range Experiment Station.USDA Forest Service WR-1 p-WR-12.

Franklin JF. 1988. Pacific Northwest forests. In: Barbour MG, Billings WD editors.. North American terrestrial vegetation. Cambridge: Cambridge University Press. p 103-30.

Franklin JF, Cromack K Jr, Denison W, McKee A, Maser C, Sedell J, Swanson F, Juday G. 1981. 16. Ecological characteristics of old-growth Douglas-fir forests. General technical report PNW-118. Portland (OR): USDA Forest Service, Pacific Northwest Research Station.

Franklin JF, DeBell DS. 1988. Thirty-six years of tree populations change in an old-growth Pseudotsuga- Tsuga forest. Can J For Res 18:633-9.
Franklin JF, Dyrness CT. 1973. Natural vegetation of Oregon and Washington. General technical report PNW-8. Portland (OR): USDA Forest Service, Pacific Northwest Research Station. $417 \mathrm{p}$.

Franklin JF, Spies TA. 1991. Ecological definitions of old-growth Douglas-fir forests. In: Ruggiero LF, Aubry KB, Carey AB, Huff $\mathrm{MH}$, technical coordinators. Wildlife and vegetation of unmanaged Douglas-fir forests. General technical report PNWGTR-285. Portland (OR): USDA Forest Service, Pacific Northwest Research Station. p 71-80.

Franklin JF, Waring RH. 1980. Distinctive features of the northwestern coniferous forest: development, structure, and function. In: Ecosystem analysis: proceedings, 40th Annual Biological Colloquium, 1979 April 27-28. Corvallis: Oregon State University. p 59-86.

Gray AN, Franklin JF. 1997. Effects of multiple fires on the structure of southwestern Washington forests. Northwest Sci 71:174-85.

Hammond PE. 1980. Reconnaissance geologic map and cross sections of southern Washington Cascade Range, latitude 45 degrees 30 minutes-47 degrees 15 minutes N., longitude 120 degrees 45 minutes-122 degrees 22.5 minutes W. Portland: Portland State University.

Hammond PE, Korosec MA. 1983. Geochemical analyses, age dates, and flow-volume estimates for Quaternary volcanic rocks, southern Cascade Mountains, Washington. Open file report 83-13. Olympia (WA): Washington Department of Natural Resources, Division of Geology and Earth Resouces. p 36.

Harmon ME. 2001. Carbon sequestration in forests. J For 99: 24-9.

Harmon ME, Bible K, Ryan MG, Shaw DC, Chen H, Klopatek J, Li X. 2004. Production, respiration, and overall carbon balance in an old-growth Pseudotsuga- Tsuga forest ecosystem. Ecosystems 7:498-512.

Harr RD. 1986. Effects of clearcutting on rain-on-snow runoff in western Oregon: A new look at old studies. Water Resour Res 22:1095-100

Heilman PE. 1981. Minerals, chemical properties and fertility of forest soils. In: Heilman PE, Anderson HW, Baumgartner DM editors.. Forest soils of the Douglas-fir region. Pullman: Washington State University. p 121-36.

Hemstrom MA, Franklin JF. 1982. Fire and other disturbances of the forests in Mount Rainier National Park. Quat Res 18:32-51.

Homan PS, Lollins P, Chappell HN, Stangenberger AG. 1995. Soil organic carbon in a mountainous, forested region: relation to site characteristics. Soil Sci Soc Am 59:1468-75.

Ishii H, Ford ED. 2002. Persistance of Pseudotsuga-menziesii in temperate forests of the Pacific Northwest Coast, USA. Folia Geobotanica 37:63-9.

Ishii H, Clement JP, Shaw DC. 2000a. Branch growth and crown form in old coastal Douglas-fir. For Ecol Manage 131: 81-91.

Ishii H, Reynolds JH, Ford ED, Shaw DC. 2000b. Height growth and vertical development of an old-growth Pseudotsuga- Tsuga forest in southwestern Washington, U.S.A. Can J For Res 30:17-24.

Janisch JE, Harmon ME. 2002. Successional changes in live and dead wood carbon stores: implications for net ecosystem productivity. Tree Physiol 22:77-89.

Kemp L, Schuller SR. 1982. Checklist of vascular plants of the Thornton T. Munger Research Natural Area. Administrative 
report PNW-4. Portland (OR). USDA Forest Service. Pacific Northwest Forest and Range Experiment Station.

King JP. 1961. Growth and mortality in the Wind River Natural Area. J For 59:768-70.

Lawrence DB. 1939. Some features of the vegetation of the Columbia River Gorge with special reference to asymmetry in forest trees. Ecol Monogr 9:217-57.

Margot BG, Holthausen RS, Teply J, Carrier WD. 1991. Oldgrowth inventories: status, definitions, and visions for the future. In: Ruggiero LF, Aubry KB, Carey AB, Huff MH, technical coordinators. Wildlife and vegetation of unmanaged Douglas-fir Forests. General technical report PNW-GTR-285. Portland (OR): USDA Forest Service, Pacific Northwest Research Station. p 47-60.

Mathiasen RL, Shaw DS. 1998. Adult sex ratio of western hemlock dwarf mistletoe in six heavily infected western hemlock. Madrono 45:210-4.

Means JE, MacMillan PC, Cromack K Jr. 1992. Biomass and nutrient content of Douglas-fir logs and other detrital pools in an old-growth forest, Oregon, U.S.A. Can J For Res 22:153646.

Meyers AP, Fredricks N. 1993. Thornton T. Munger Research Natural Area management plan. USDA Forest Service. On file Gifford Pinchot National Forest. Vancouver (WA). p 62.

Parker GG, Harmon ME, Lefsky MA, Chen J, Van Pelt R, Weiss SB, Thomas SC, Winner WE, Shaw DC, Franklin JF. 2004. Three-dimensional structure of an old-growth PseudotsugaTsuga canopy and its implications for radiation balance, microclimate, and atmospheric gas exchange Ecosystems 7:440-53.

Paw U KT, Falk M, Suchanek TH, Ustin SL, Chen J, Park Y-S, Winner WE, Thomas SC, Hsiao TC, Shaw RH, and others. 2004. Carbon dioxide exchange between an old-growth forest and the atmosphere. Ecosystems 7:513-24.

Perry DA, Pitman GB. 1983. Genetic and environmental influences in host resistance to herbivory: Douglas-fir and the western spruce budworm. Z Angew Entomol 96:217-28.
Radwan MA. 1992. Effect of forest floor on growth and nutrition of Douglas-fir and western hemlock seedlings with and without fertilization. Can J For Res 22:1222-9.

Schowalter TD, Ganio LM. 1998. Vertical and seasonal variation in canopy arthropod communities in an old-growth conifer forest in southwestern Washington, USA. Bull Entomol Res 88:633-40.

Schoonmaker PK, Von Hagen B, Wolf EC. 1997. The rain forests of home. Washington (DC): Island.

Shaw DC, Freeman EA, Mathiasen RL. 2000. Evaluating the accuracy of ground based hemlock dwarf mistletoe rating: a case study using the Wind River canopy crane. West J Appl For 15:8-14.

Thomas SC, Winner WE. 2000. Leaf area index of an old-growth Douglas-fir forest: an estimate based on direct structural measurements in the canopy. Can J For Res 30:1922-30.

Topik C, Halverson NM, Brockway DG. 1986. Plant association and management guide for the Western Hemlock Zone, Gifford Pinchot National Forest. R6-ECOL-230A-1986. Portland (OR): USDA Forest Service, Pacific Northwest Research Station. p 133.

Walsh TJ, Korosec MA, Phillips WM, Logan RL, Schasse HW. 1987. Geologic map of Washington: southwest quadrant-geologic map GM-34. Olympia: Washington State Department of Natural Resources.

Wise WS. 1961. Geology and mineralogy of the Wind River area, Washington, and the stability relations of celadonite [dissertation]. Baltimore (MD): Johns Hopkins University.

Wise WS. 1970. Cenozoic volcanism in the Cascade Mountains of southern Washington. Wash Div Mines Geol Bull 60:1-45.

Woodfin RO Jr, DeBell DS, Franklin JF. 1987. Wind River Experimental Forest Research Management Plan. USDA Forest Service. On file: Pacific Northwest Forest and Range Experiment Station (now, Pacific Northwest Research Station), Portland (OR).

Youngberg CT. 1966. Forest floor in Douglas-fir forests. I. Dry weight and chemical properties. Soil Sci Soc Am J 30: 406-9. 